Proc. Estonian Acad. Sci. Geol., 2005, 54, 4, 209-224

\title{
Slope processes at the North Estonian Klint
}

\begin{abstract}
Avo Miidel and Anto Raukas
Institute of Geology at Tallinn University of Technology, Estonia pst. 7, 10143 Tallinn, Estonia; miidel@gi.ee,raukas@gi.ee

Received 26 May 2005, in revised form 8 September 2005

Abstract. Due to the rather flat topography slope processes in Estonia are rare and fairly superficially investigated. Mass movements are often related to the North Estonian Klint - the middle part of the $1200 \mathrm{~km}$ long Baltic Klint. Since the basal part of the klint is dominated by Cambrian clays and Cambrian and Ordovician silt- and sandstones, which are covered with hard Ordovician carbonate rocks, different types of mass movement take place, including rock falls, rock slides, rotational slips, etc. The greatest gravitational processes occur between the Island of Osmussaar and Tiskre, and in the area extending from Kalvi to Päite. In the paper the most common types of mass movements are analysed and described.
\end{abstract}

Key words: North Estonian Klint, slope processes, mass movements, rock falls, rock slides, rotational slips, talus creep.

\section{INTRODUCTION}

The term klint, widely used in the countries around the Baltic Sea, is originally a Danish and Swedish word synonymous with klev, signifying an escarpment in sedimentary rocks. In the German and Russian languages the word glint is preferred and in former times such a form was adopted also in Estonia (Tammekann 1940). In English the word is sometimes written as clint. In recent decades, the term klint has been used in English (Raukas 2004) and also in most of the other languages (klints in Latvian, klintas in Lithuanian).

Klints of different age occur in the Baltic Sea area. The Baltic (Ordovician) Klint is best known in the region and the highest klint in Estonia. It extends as an almost continuous, but indented and lobated arc from the western coast of the Island of Öland in Sweden over the Baltic Sea via the northern coast of Estonia to Lake Ladoga in Russia (Fig. 1). 


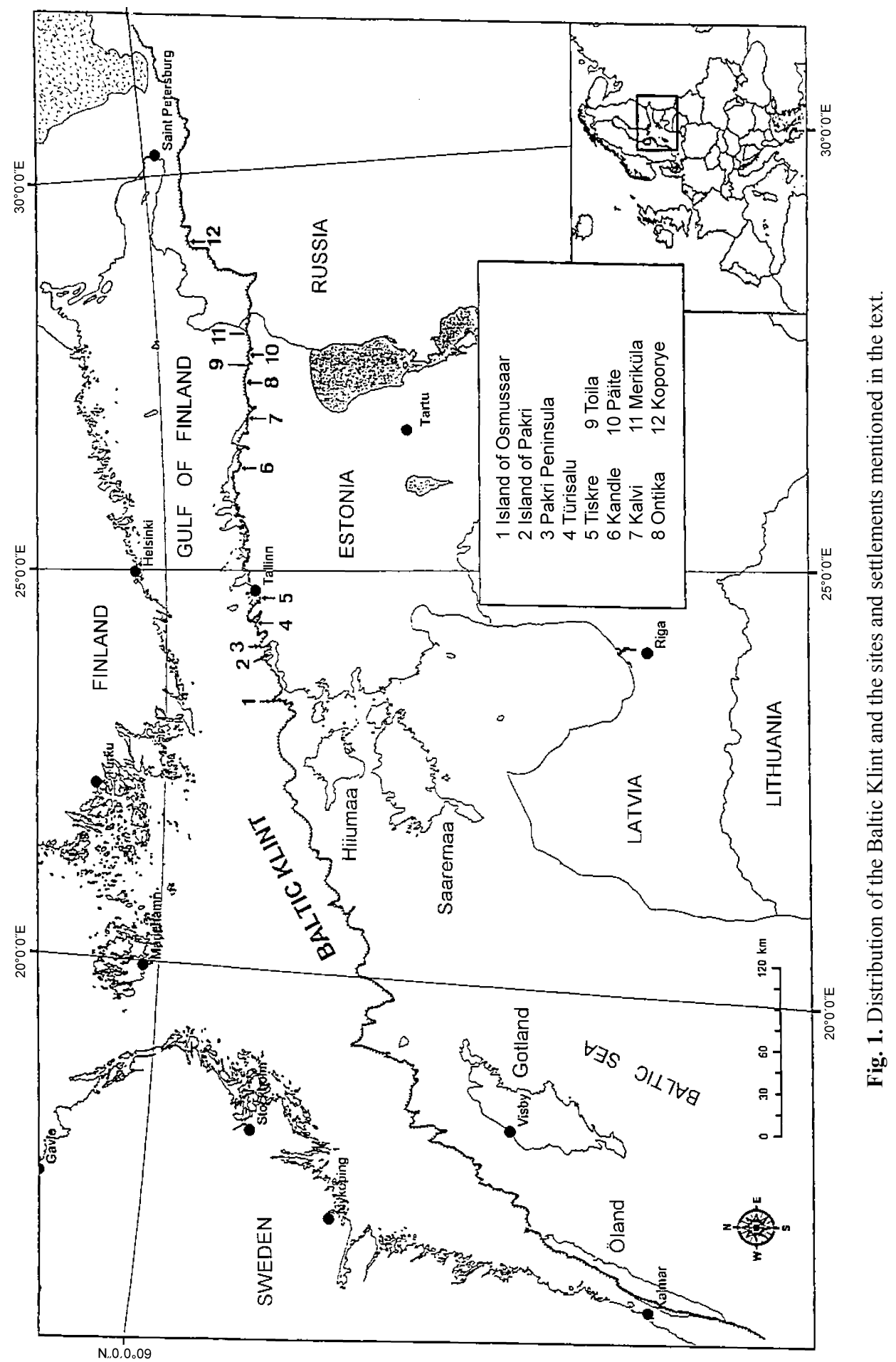


In 2004, the Baltic Klint, represented by seven selected sections in North Estonia, was nominated for inclusion in the World Heritage List as one of the longest continuous escarpments in the world, where fossil-rich Cambrian and Ordovician rocks can be followed in a wide geographical and geological extent. The escarpment exposes sedimentary rocks undisturbed by tectonic and metamorphic processes and serves as an excellent basis for the compilation of Cambrian and Ordovician regional and local stratigraphical charts (Raukas \& Teedumäe 1997). The klint exposures include several internationally recognized stratotypes.

The geological, geomorphological, stratigraphical, and palaeogeographical aspects of the North Estonian Klint have been discussed in many works (see references in Suuroja 2005). Slope processes have received less attention, although these are widespread even in the seemingly stable eastern part of the klint. The aim of this paper is to draw attention to mass movements resulting in the ongoing recession of the klint.

\section{GEOLOGICAL SETTING}

The Baltic Klint, formed of Cambrian and Ordovician rocks on the boundary of the Fennoscandian Shield and the Russian Platform, is not only a steep escarpment but is often identified as a system of terraces separated by escarpments (Tammekann 1940; Suuroja 2003, 2005). The klint defined in this way is $2-50 \mathrm{~km}$ wide and known in the literature as the Cambrian-Ordovician Klint (Martinsson 1958) or the Baltic-Ladoga Klint (Lamanski 1901).

The absolute height of this $1200 \mathrm{~km}$ long monumental escarpment is over $140 \mathrm{~m}$ at Koporye (Russia), about $68 \mathrm{~m}$ near Kandle, and $56 \mathrm{~m}$ at Ontika (Estonia), the last one being the greatest relative height of the klint. The basal part of the klint in the eastern flank consists of Cambrian rocks dominated by sand- and siltstones and "blue clays". The hard crest layers of the klint, which primarily cause the steepness of the escarpment, consist of Lower and Middle Ordovician limestones (Orviku 1940). In the westernmost part of Öland Island the klint crest is developed exclusively in Lower Ordovician limestone beds. The submarine Ordovician klint as a morphological feature is identified on sea charts and established mainly with geophysical methods (Tuuling \& Flodén 2001; Noormets \& Flodén 2002). The most significant part of the Baltic Klint is located in mainland Estonia on the southern coast of the Gulf of Finland and is known as the North Estonian Klint. Here it is dissected by river valleys with more than 20 picturesque waterfalls (Aaloe \& Miidel 1967; Miidel 1997). Valaste, the highest (30 m) waterfall of the klint, is located near Ontika (Fig. 1).

Morphologically, the North Estonian Klint is divided into several parts (klint bays, klint peninsulas, etc.). Within the escarpment several morphological types are distinguished (Giere 1932; Tammekann 1940; Suuroja 2003). Regionally, the klint was divided into four parts within which 37 smaller units were differentiated 
(Tammekann 1940). The most recent classification (Suuroja 2003, 2005) consists of nine parts with 95 smaller units.

Although the first traces of distinct escarpment formation on the territory of Estonia date from the Late Silurian and pre-Middle Devonian continental period, the main features of bedrock topography, including the Baltic Klint, originate from the Meso- and Cenozoic (Puura et al. 1999). Prolonged pre-Pleistocene erosional-denudational processes affecting the structural changes in the Precambrian crystalline basement and the non-metamorphic sedimentary cover were of utmost importance. The sedimentary cover has a gentle southward inclination $\left(6-18^{\prime}\right)$. Due to the tectonic uplift new and new areas were influenced by lateral river flows, forming a questa-like topography with steep northern and gentle southern slopes. The influence of the old drainage systems on the klint evolution is evident. So, the Ordovician Klint system was generated at its whole length by the erosion of soft, mainly Cambrian sandstone, siltstone, and clay strata overlain by much more resistant limestones, which determines the retreat of the klint and accounts for the relative steepness of the feature.

During the ice ages the North Estonian Klint was strongly influenced by glacial erosion. After the retreat of the continental ice it was modelled by wave action during different stages of the Baltic Sea. This influence varied because different parts of the klint rose above sea level at different times (Orviku \& Orviku 1969). At Ontika in NE Estonia the North Estonian Klint was subject to wave action already during the Baltic Ice Lake more than 11000 years ago, on the Island of Osmussaar in NW Estonia it appeared above sea level only some 2000 years ago. Due to land uplift the klint edge is in some places kilometres away from the seashore, in other places it is subject to immediate sea erosion, while in some places it is currently emerging from the sea waters.

Slope processes started immediately after one or another part of the klint had emerged from the sea. According to Orviku \& Orviku (1969), in the Baltic Ice Lake stage $\mathrm{B}_{\text {III }}$ (ca $10300{ }^{14} \mathrm{C}$ years ago) the klint already existed at Ontika as an about $27 \mathrm{~m}$ high cliff with the waves eroding both the Ordovician carbonate rocks and Dictyonema argillite. Undoubtedly, already at that time the first rock falls occurred here. Afterwards, when the talus had formed, other types of mass movements were added (landslide, talus creep, etc.).

\section{GEOLOGICAL PRECONDITIONS FOR GRAVITY EROSION}

The geological structure of the klint changes substantially along the shoreline of the Gulf of Finland. In the west, on the tip of the Pakri Peninsula, the thickness of Ordovician carbonate rocks is 6-7 m. It increases in an easterly direction, reaching almost $14 \mathrm{~m}$ at Ontika (Figs. 2, 3) where these rocks are strongly dolo-

mitized. The total thickness of Ordovician terrigenous rocks decreases from $12 \mathrm{~m}$ on Pakri Cape (the northern tip of the Pakri Peninsula) to $7 \mathrm{~m}$ at Ontika, while the 


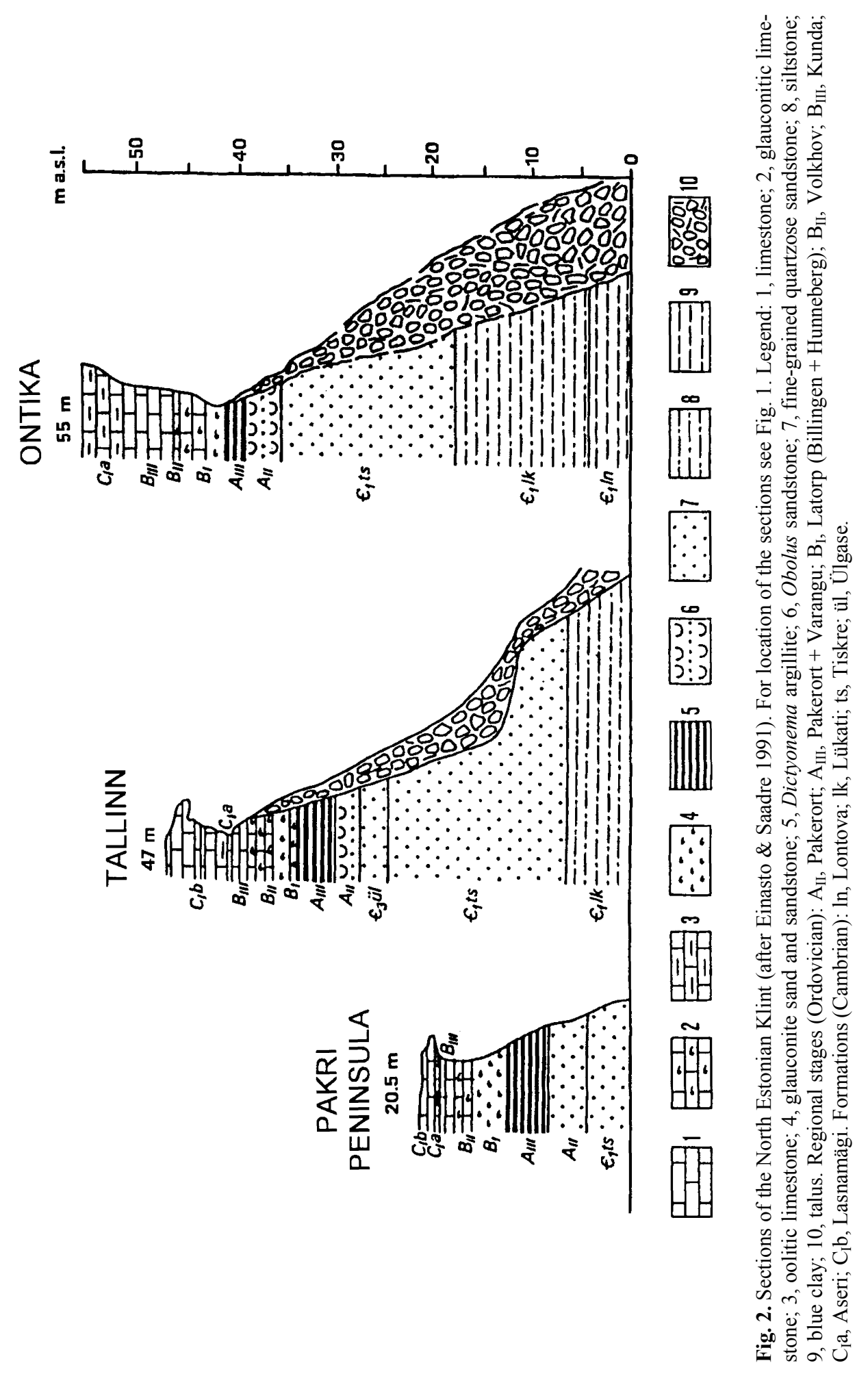




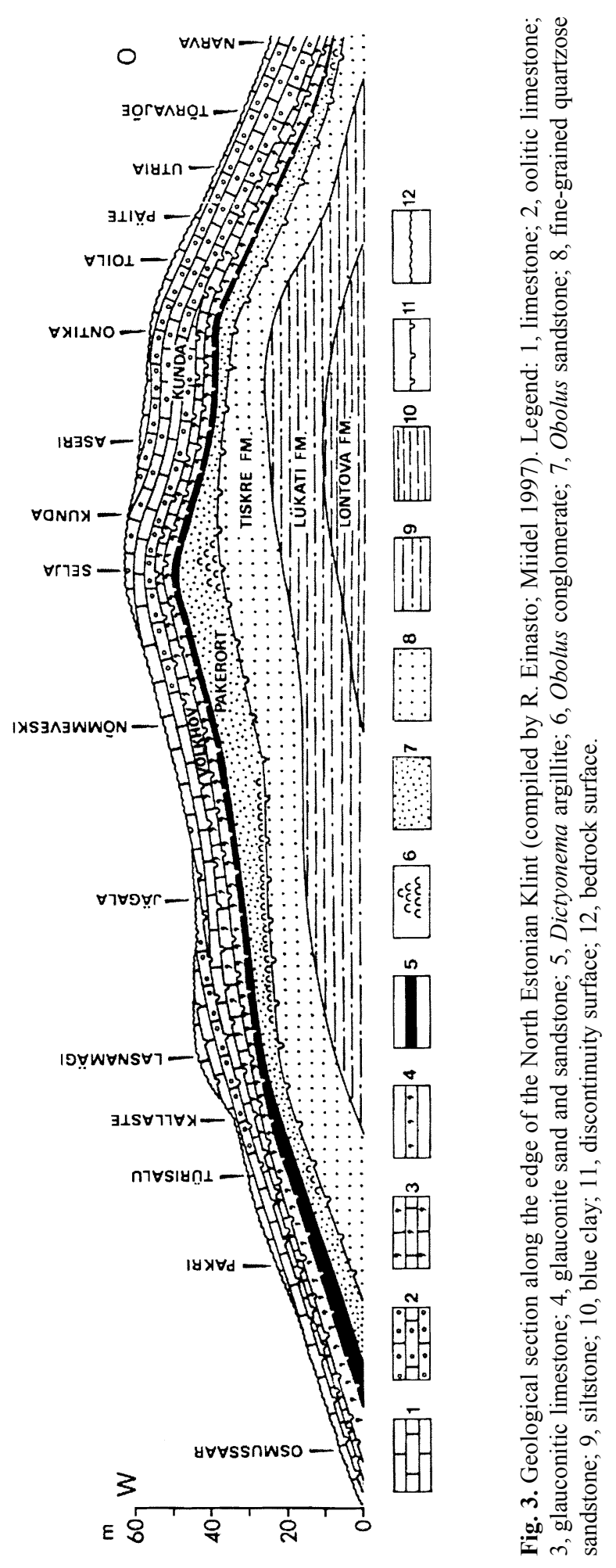


thickness of Cambrian terrigenous rocks, represented mainly by siltstones and clays, increases from 4 to $30-35 \mathrm{~m}$. The exposure of clayey rocks on the klint and in front of it is a geological precondition for talus creep and landslides. The klintforming rocks vary in hardness; the most resistant rocks are exposed in the upper part of the terrace. Tammekann (1926) measured the hardness of these rocks on a six-point scale. According to him, carbonate rocks had a hardness of 4-6. The resistance of rocks to erosion also depends on their clay content and thickness of layers. Thin-bedded limestones with marl intercalations are more prone to erosion. Tammekann (1926) showed that the glauconitic limestones of the Toila Formation are the hardest limestones ( 6 pts). The softest rocks are, undoubtedly, the glauconitic sand and sandstones of the Hunneberg Stage (Leetse Formation) and the sandstone of the Pakerort Stage (Kallavere Formation) with a relative hardness of 2-3. In Tammekann's opinion, graptolitic argillite is as soft as glauconitic sand; however, to our mind, this is not correct. Graptolitic argillite is evidently harder because in the outcrops it forms a cornice above the underlying layers. According to Tammekann, the sandstones of the Tiskre Formation are a bit softer than the rocks of the Lükati Formation - hardness 2-4 and 4, respectively. Actually, the hardness of both formations is rather changeable depending on the number and thickness of clayey interlayers. In general lines, the rocks of both formations, however, are rather unresistant to erosion. Joints in the rocks play a very important role in gravity erosion (Fig. 4). According to Teichert (1927) and Heinsalu \& Andra (1975), joints of NW-SE, NE-SW, N-S, and W-E orientation prevail, whereas the azimuths of the prevailing joints in East Estonia are $285-345^{\circ}$ (max $\left.315^{\circ}\right), 40-75^{\circ}\left(\max 55^{\circ}\right), 345-10^{\circ}\left(\max 355^{\circ}\right)$, and $75-105^{\circ}\left(\max 85^{\circ}\right)$, respectively. Among the joints of NE-SW orientation two intervals can be distinguished: 45-65 and $20-40^{\circ}$. The same directions are prevailing in Tallinn and Paldiski and can be traced partly on the Island of Osmussaar (Thamm 1962). In several places in northeastern Estonia submeridional joints (azimuth $355-5^{\circ}$ ) dominate (Heinsalu \& Andra 1975).

The density of joints in eastern and western Estonia is somewhat different. It is especially high in eastern Estonia, where the distance between the joints, regardless their orientation, is often only $5-10 \mathrm{~cm}$. The mean distance between the joints of NW-SE direction is $0.5-3 \mathrm{~m}$ (seldom up to $10 \mathrm{~m}$ ). Between the joints of NE-SW orientation it is $2-3.5 \mathrm{~m}$, seldom $25-40 \mathrm{~m}$. The joints of the orthogonal system are rarest, with the distance between them being $8-40 \mathrm{~m}$. It should be pointed out that joints are more numerous in carbonate rocks than in terrigenous rocks. Also their directions may be different. For instance, at Toila orthogonal joints dominate in sandstones, while diagonal joints prevail in carbonate rocks (Teichert 1927). Joints divide rocks into blocks of variable size. Owing to this, water can penetrate into the otherwise impermeable carbonate rocks and underlying layers. Both the joints and horizontal bedding of rocks trigger and essentially promote the development of mass movements. This means that the intensity and character of mass movements depend on the lithology, morphology, and tectonic framework of the klint and are highly influenced by coastal erosion 


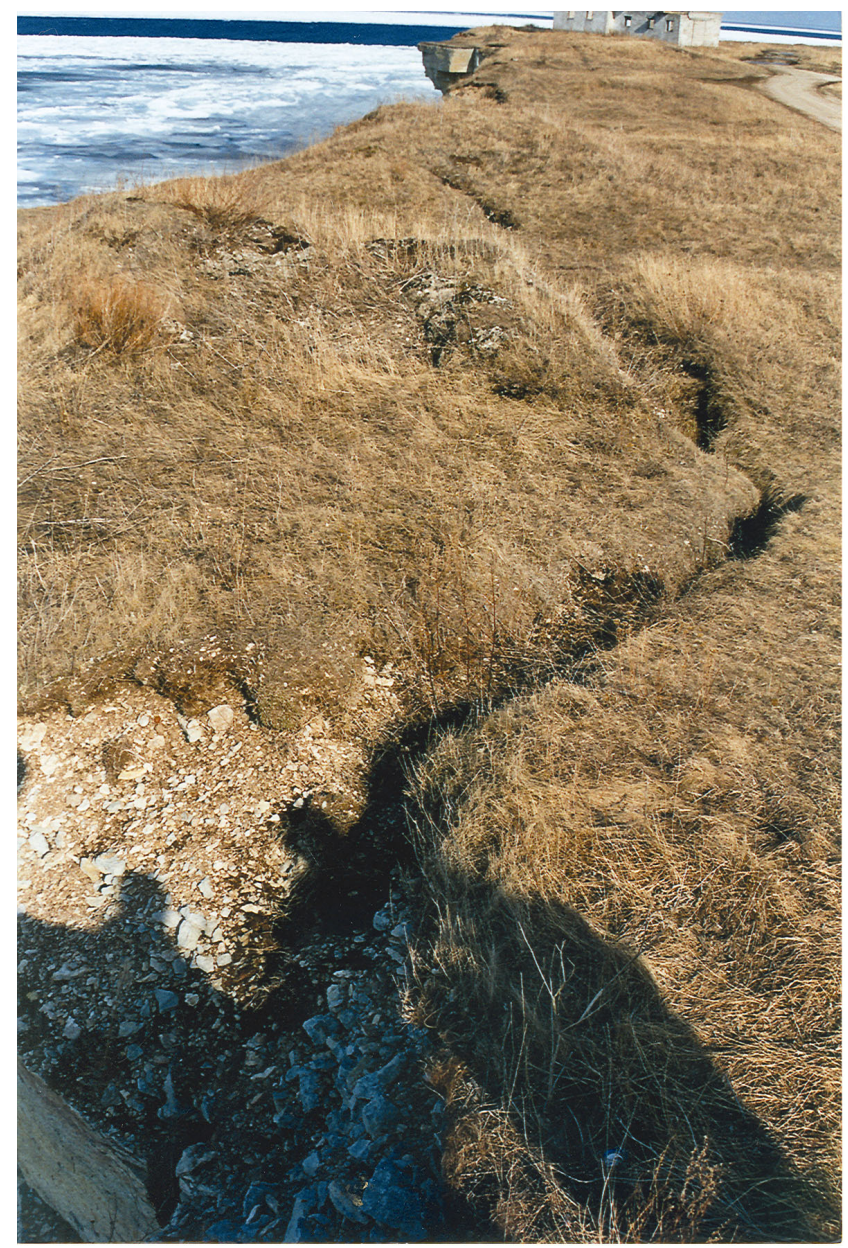

Fig. 4. A block of rocks bounded by open joints at Pakri Cape (27 March 2003). Photo by A. Miidel.

and human activity. Rock falls can also be released by earthquakes. For example, the Osmussaar earthquake (4.7 magnitudes in Richter's scale) in 1976 caused several rock falls along the northern and northeastern coasts of the Island of Osmussaar (Klaamann 1977; Nikonov 2002).

\section{MASS MOVEMENTS IN THE KLINT}

Mass movements in the klint area have been studied since the 19th century. Eichwald (1840) described the retreat of the klint on the Island of Osmussaar. Helmersen (1856) presented data on rock falls and stressed the role of tectonic joints in their occurrence. Vilbaste (1939) indicated the significance of landslides and soil creep in the development of the fore-klint talus in eastern Estonia. 
Discussing the development of contemporary cliffs, Orviku (1984) pointed out differences in the resistance of rocks to erosion and the role of tectonic joints, which essentially influence the morphology of cliffs. Using the classification by Hutchinson (1968), the following types of mass movements could be distinguished in the region of the North Estonian Klint: rock falls, rock slides (or block glides), rotational slips, and talus creep.

\section{Rock falls}

Rock falls are mentioned by several authors (Helmersen 1856; Vilbaste 1939; Tammekann 1940) in the areas where the klint is exposed immediately at the sea (Figs. 2, 5,6) or only a little away from the waterfront. Within these sections,

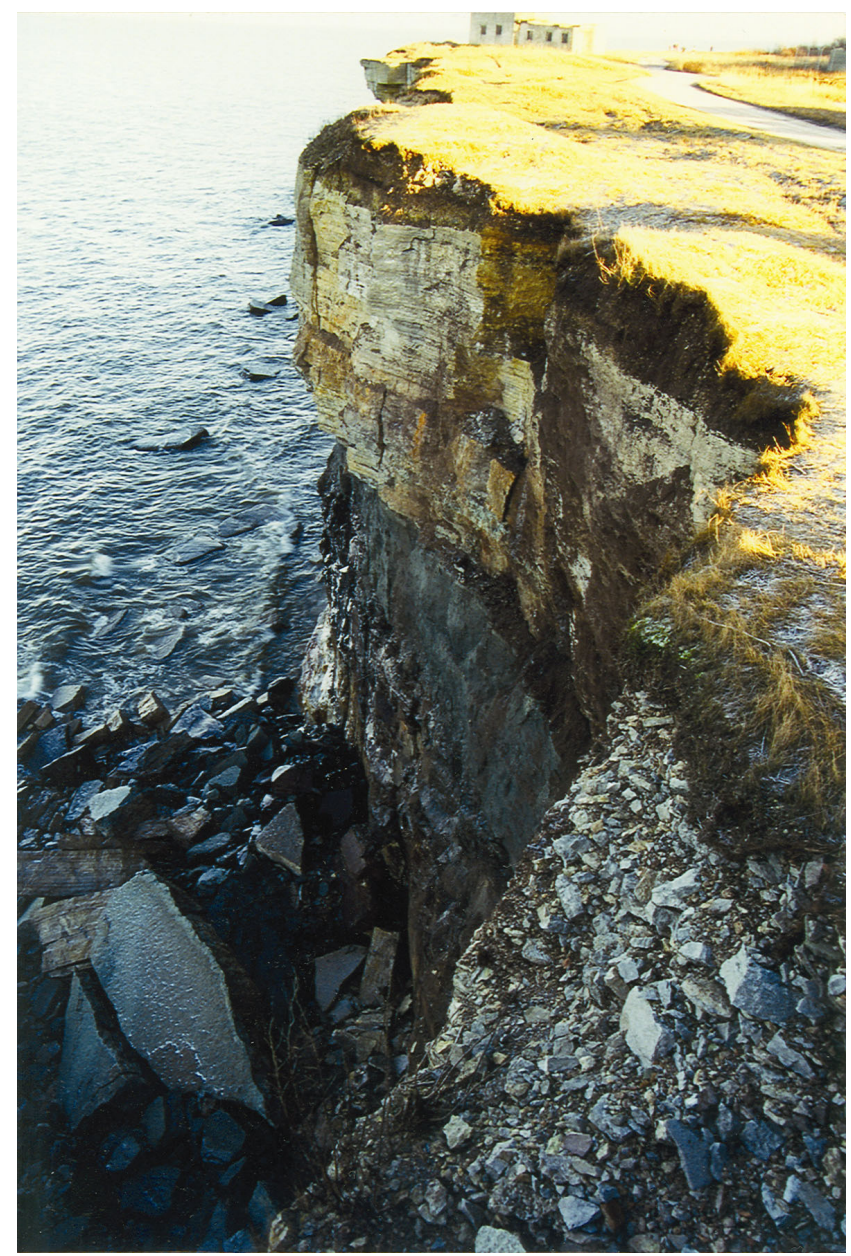

Fig. 5. The block at Pakri Cape (Fig. 4) fell down at the end of December 2003. Photo by A. Miidel. 


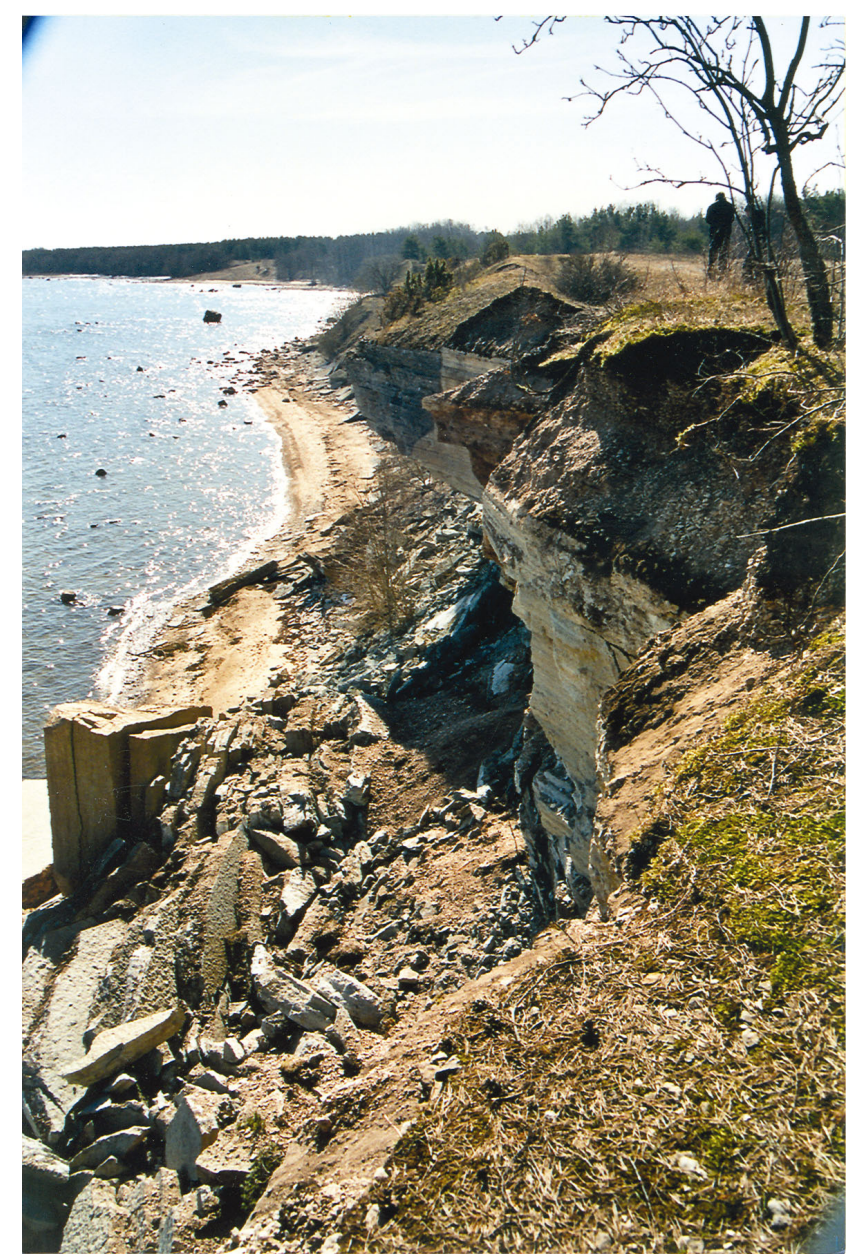

Fig. 6. A rock fall took place in the spring of 2004 at Leetse, Pakri Peninsula. Photo by A. Miidel.

extending from the Island of Osmussaar to Tiskre and from Kalvi to Meriküla (Fig. 1), the uppermost steep part of the klint consists of hard Ordovician rocks. Rock falls are probably the main factor related to the formation of the broad and thick talus in front of the klint in eastern Estonia. The material ranges from angular debris of variable size up to big boulders and blocks (Fig. 5). The size of the material depends on the spatial distribution of tectonic joints. In the areas with a high frequency of joints (10-20 joints per metre) the debris is smaller in size than in the areas where the distance between the crossing sets of joints is large $(5-25 \mathrm{~m})$. Finer material is also derived from the downfall of finely laminated clayey carbonaceous rocks. The freeze-thaw processes taking place in the joints 
are the main agents responsible for the formation of rock falls. As is known, water expands by $9 \%$ when it freezes. This creates a pressure up to $1000 \mathrm{kG} \mathrm{cm}^{-1}$ in pores and joint walls (Lomtadze 1970). Freeze-thaw processes repeat from year to year and push the joints more and more apart. Separated blocks break loose, but for some time they may preserve as columns (Fig. 7). The length of the blocks that have fallen down may reach 50-70 m.

The uppermost part of the carbonate cap rock complex consists of the most resistant lime- and dolostones of the Väo Formation belonging to the Lasnamägi and Uhaku regional stages. They hang as a cornice over softer thin-bedded carbonate rocks of the Aseri, Kunda, and Volkhov regional stages (see the stratigraphic

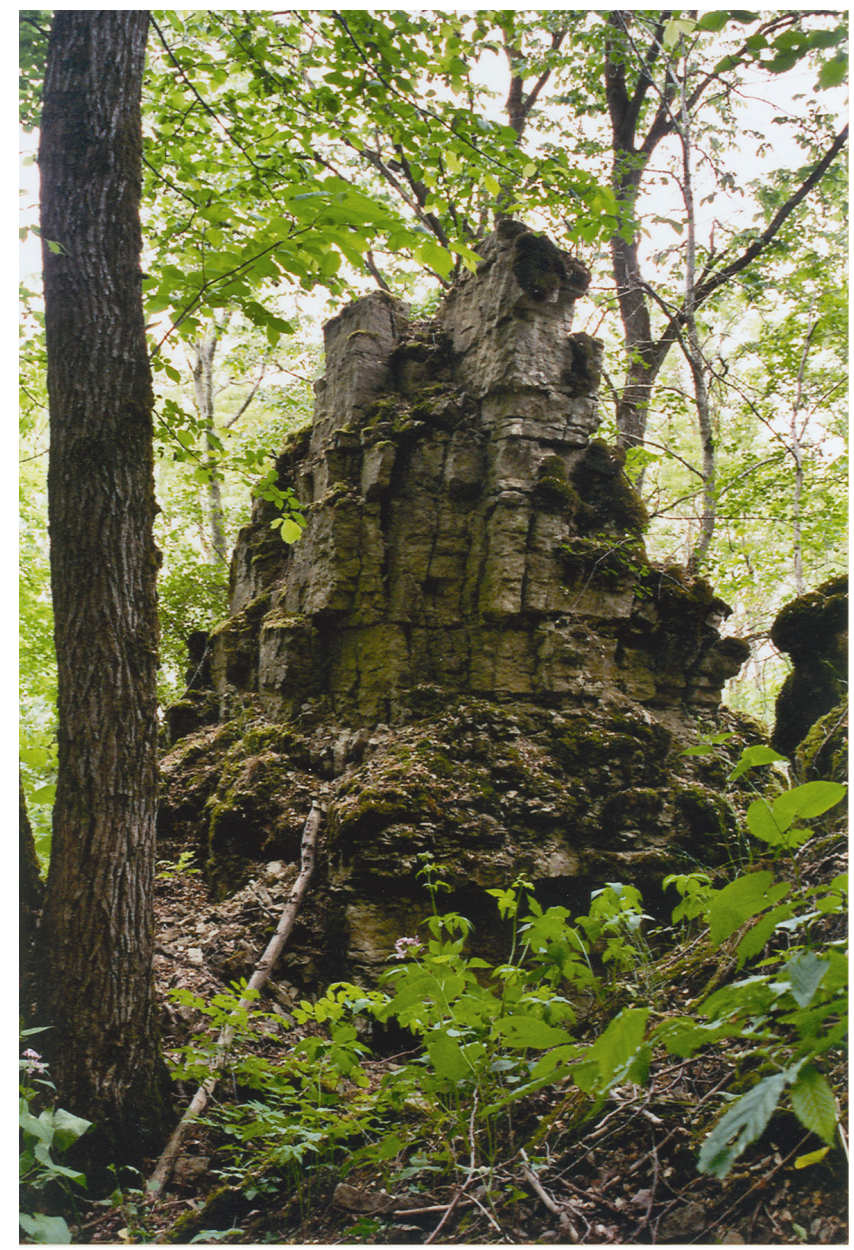

Fig. 7. A column of Ordovician carbonate rocks at Ontika. Photo by A. Miidel. 
chart in Raukas \& Teedumäe 1997, pp. 54-55). The latter rocks, in their turn, form a cornice above the Ordovician and Cambrian terrigenous rocks. Due to the joints running through the cap rock complex, the water can penetrate into the soft terrigenous complex, causing its steady erosion and promoting the expansion of notches and caves. Typical rock falls are related to the cap rock complex, which seldom includes underlying rocks.

It was not until 1991 that precise data on rock falls could be obtained. In all likelihood, rock falls took place earlier as well, but during the Soviet occupation the klint was difficult to access, because it was situated in a strictly guarded border zone. Therefore, regular registration and investigation of rock falls proved impossible. During the last decade several large rock falls have taken place on Pakri Cliff (Figs. 4, 5). One of the largest rock falls occurred on 22 April 1996. On the tip of the peninsula it caused so strong shaking of the ground that at first an earthquake was considered as a reason for the rock fall. In December 2003, evidently during a heavy storm, an arch-like block, $9.4 \mathrm{~m}$ wide and $27 \mathrm{~m}$ long, was involved in the rock fall (Figs. 4, 5). The mass of the material fallen down was some 1500-2000 tonnes. At the end of March or beginning of April 2004 a rock fall occurred at Leetse on the northeastern coast of the Pakri Peninsula (Fig. 6). The resulting amount of downfallen material is evidently greater than that of the rock fall registered on the Pakri Cape at the end of 2003. Rock falls are dangerous for people in this region because Pakri Cliff is an important sightseeing object for tourists.

Judging by extensive stone fields and stone heaps, rock falls are rather frequent on the klint stretch between Kalvi and Päite (Fig. 1).

\section{Rock slides}

Rock slides (or block glides) are confined to the first and third sections of the klint (Fig. 1) where steep vertical walls consist of carbonate rocks and form the upper part of the escarpment. The slip surface is commonly formed by joint planes. It is not always possible to distinguish a rock fall from a rock slide. They are both related to joint nets, but rock slides are mostly associated with the terrigenous rocks in the lower part of the klint. In both cases, the repeated cycles of freezing-thawing of water in the joints of weathered rocks play a very important role. In Toila settlement and its immediate surroundings several houses built on the edge of the klint are in danger of falling down. As a result of rock slides and falls, the klint is retreating in eastern Estonia. In some places, the edge of the escarpment reaches the old Tallinn-St. Petersburg highway and some mileposts are even on the verge of falling down. In the case of rock slides the rock block remains relatively monolithic and is not crushed to the extent it does as a result of rock falls. Often, the downsliding beds face the sea (Fig. 8). 


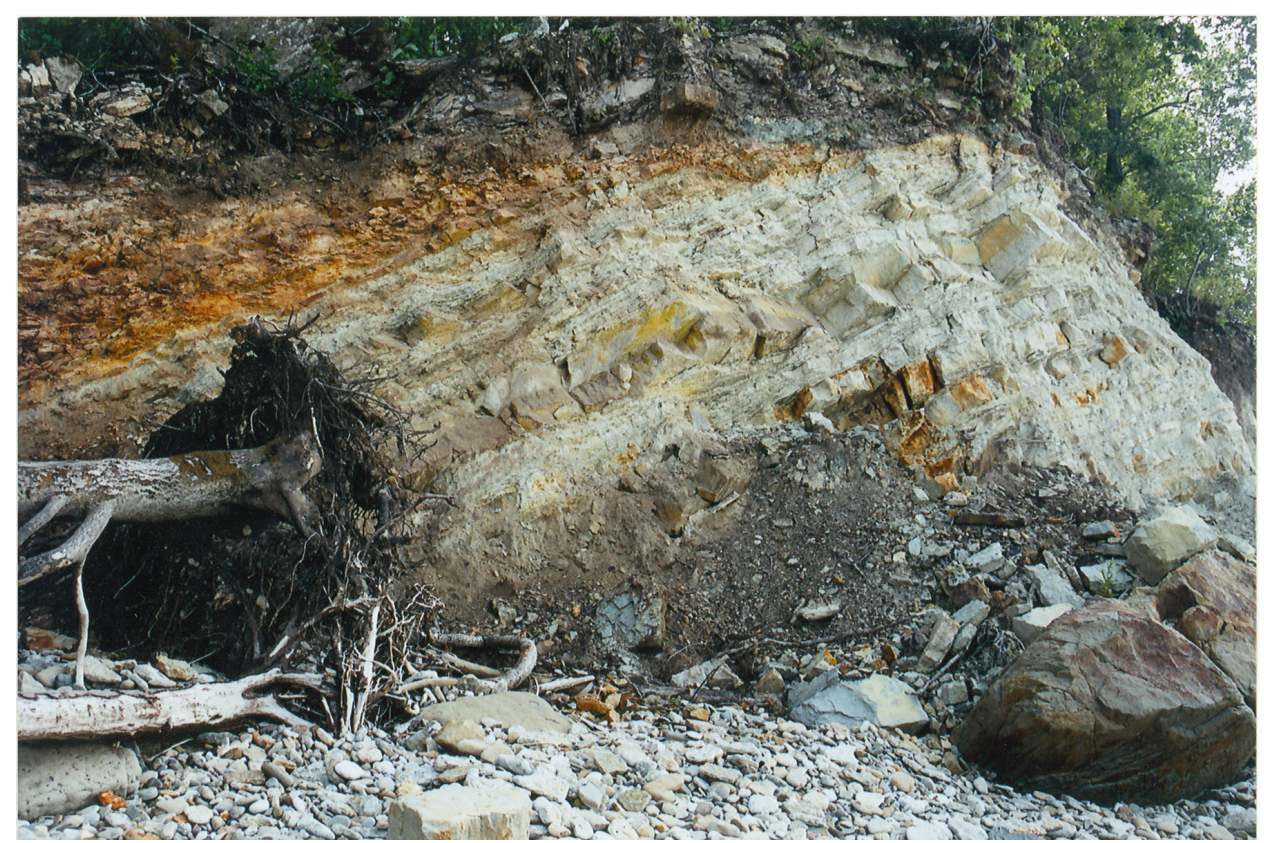

Fig. 8. A block of Cambrian rocks on the seashore in the vicinity of Voka. The block was detached from the klint by a rock slide and slipped down as a result of the creep. Photo by A. Miidel.

\section{Rotational slips}

This type of landslides is related to the specific talus, widely distributed in the klint section Kalvi-Meriküla (Fig. 1) where the talus is underlain by Cambrian "blue clays". Slips take place by shearing on a somewhat cylindric slip surface. In most cases, these slips belong to single rotational type. Multiple rotational slips are not known so far. Such landslides may be triggered by heavy storms or rainfalls when the toe of the talus slope is eroded away. The most recent landslide took place at Toila in May 2001. The landslide was about $180 \mathrm{~m}$ long and formed a transverse ridge. The main scarp was $3 \mathrm{~m}$ high. It might have been a rock slide, because also part of the bedrock was involved; the bedrock fell on the talus and piled it up into a rampart. Rotational slips may occur at the sea in the talus (Fig. 9) or in the clayey bedrock. In both cases, but particularly in the former, sea erosion during the high-water stand plays a significant role, changing the equilibrium of the talus. The equilibrium can, however, also be disturbed by rock falls and root systems of large trees. When the trees are moving back and forth because of strong wind, their crowns act as wind-catching sales. 


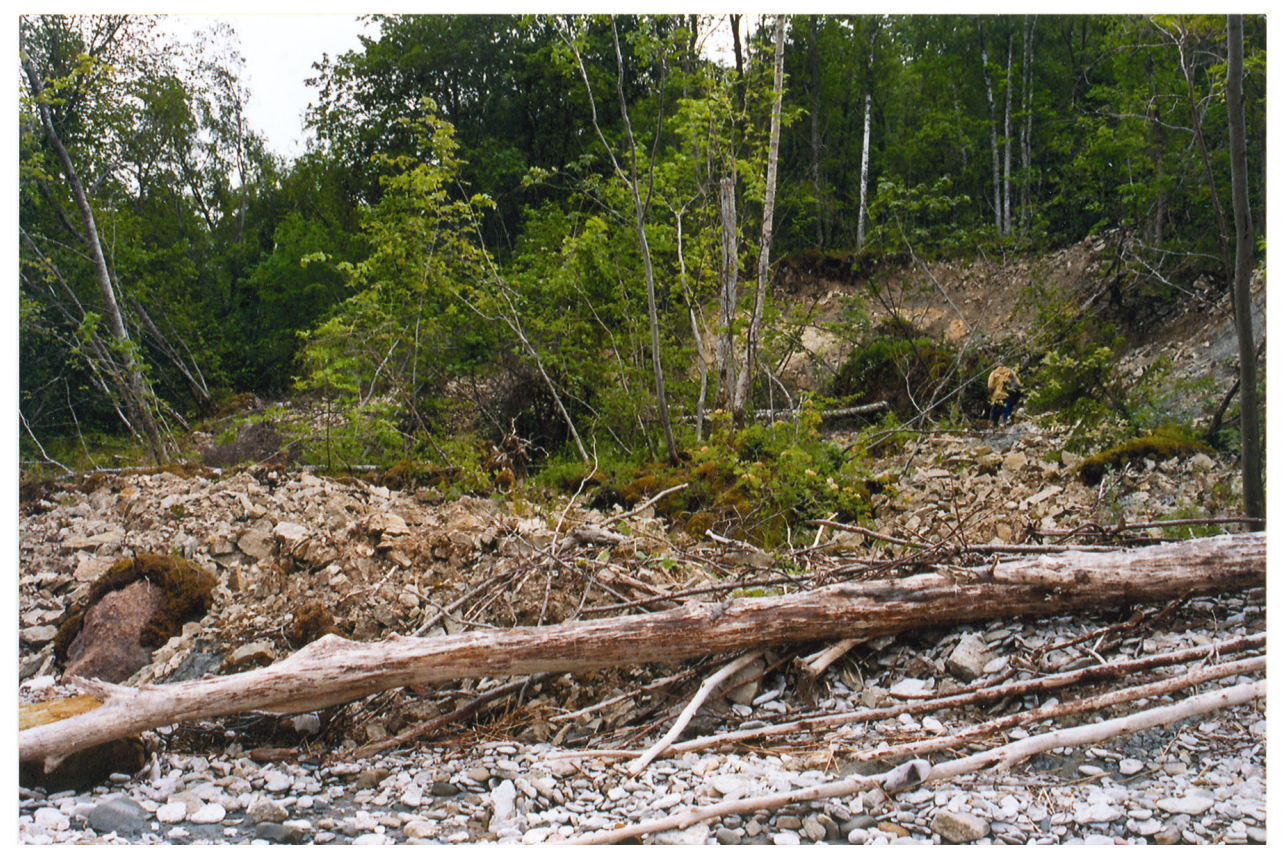

Fig. 9. A small landslide (rotational slip) in the talus, west of Ontika. Photo by A. Miidel.

\section{Talus creep}

Talus creep involves the very slow downslope movement of the layers of the talus, which typically occupies the foot of the escarpment, being at its thickest between Kalvi and Päite (Fig. 1). The material forming the talus ranges from clay particles to large bedrock blocks. Its contact with underlying Cambrian clays serves as a drainage pathway of groundwater percolating through the bedrock and discharging at the foot of the klint. This boundary acts as a lubricant favouring the talus creep. The process is accelerated by temperature and groundwater fluctuations, and freezing-thawing of water. As a result of talus creep, large blocks of Ordovician carbonate and Cambrian and Ordovician terrigenous rocks are found at the shore, 50-100 $\mathrm{m}$ away from the klint. For instance, near Toila settlement the dolomitized limestones of the Toila Formation are in a vertical position. Blocks of Cambrian and Ordovician terrigenous rocks are also frequent. These rocks crop out in the lower and middle parts of the klint. The strata in these blocks are usually inclined towards the cliff.

\section{CONCLUSIONS}

In the area under consideration mass movements are represented by rock falls, rock slides, rotational slips, and talus creep. In the western part of the North 
Estonian Klint rock falls dominate, while in its eastern part these processes are more variegated. Differences in mass movements between the above-mentioned regions are caused by differences in the geological structure. Talus is lacking in front of the klint in West Estonia and, therefore, rock falls prevail there. In East Estonia, where the talus zone overlies Cambrian clayey rocks, rotational slips and talus creep occur. Clayey rocks also promote rockslides. Due to differences in the glacioisostatic uplift and klint morphology, mass movements started in the eastern part of the klint earlier than in the western part.

\section{ACKNOWLEDGEMENTS}

The present study was financed by the State target funding project No. 0331759s01 and supported by the Estonian Science Foundation (grant No. 5342). We wish to thank Helle Kukk for typing and preliminary linguistic improvement of the text and Rein Vaher for drawing the figures. Our special thanks go to the referees of the paper Prof. Urve Miller and Dr. Tiit Hang for their valuable comments.

\section{REFERENCES}

Aaloe, A. \& Miidel, A. 1967. Eesti pangad ja joad. Eesti Raamat, Tallinn.

Eichwald, E. 1840. Kurze Anzeige einer geognostischen Untersuchung Estlands und einiger Inseln der Ostsee. Die Urwelt Russlands, durch Abbildungen erläutert, Vol. 1. St. Petersburg.

Einasto, R. \& Saadre, T. 1991. Põhja-Eesti klint. Eesti Loodus, 12, 690-695.

Giere, W. 1932. Morphologie der estländischen Nordküste. Veröff. des Geogr. Inst. Albertus Univ. z. Königsberg i Pr., N. F. Reiche Geogr., 6, 1-119.

Heinsalu, Ü. \& Andra, H. 1975. Jointing in the Estonian Oil Shale Basin and Geophysical Research Methods for its Study. Valgus, Tallinn (in Russian).

Helmersen, G. 1856. Die regelmässige Zerklüftung des Kalksteins der untern silurischen Formation an der Küste Estlands und seine Zerstörung durch die Brandung. Vorkommen von Asphalt in dieser Formation. Bull. cl. phys.-math. Acad. Sci. St. Pétersb., XIV, 13-14, 212-217.

Hutchinson, J. N. 1968. Mass movement. In The Encyclopedia of Geomorphology. Encyclopedia of Earth Sciences, Series III (Fairbridge, R. W., ed.), pp. 688-695. Reinhold Book Corp., New York.

Klaamann, E. 1977. Kõigi aegade tugevaim maavärin Eestis. Eesti Loodus, 6, 338-344.

Lamanski, V. V. 1901. Studies in the region of the Baltic-Ladoga Klint in summer 1900. Izv. Geol. Komiteta, XX, 5, 233-277 (in Russian).

Lomtadze, V. D. 1970. Engineering Geology. Engineering Petrology. Nedra, Leningrad (in Russian).

Martinsson, A. 1958. The submarine morphology of the Baltic Cambro-Silurian area. Bull. Geol. Inst. Univ. Uppsala, 38, 11-35.

Miidel, A. 1997. Escarpments and waterfalls. In Geology and Mineral Resources of Estonia (Raukas, A. \& Teedumäe, A., eds.), pp. 391-395. Estonian Academy Publishers, Tallinn.

Nikonov, A. A. 2002. The Osmussaar earthquake on 25th of October 1976: macroseismics, seismotectonics, source mechanism. Fiz. Zemli, 8, 74-88 (in Russian).

Noormets, R. \& Flodén, T. 2002. Glacial deposits and ice-sheet dynamics in the north-central Baltic Sea during the last glaciation. Boreas, 31, 362-377. 
Orviku, K. jun. 1940. Lithologie der Tallinn-Serie (Ordovizium Estland). Acta Comment. Univ. Tartuensis, A36, 1, 1-216.

Orviku, K. 1984. Eesti nüüdispankade morfoloogia ja geoloogilise arengu seaduspärasusi. In Eesti Geograafia Seltsi aastaraamat 1980 (Rõuk, A.-M., ed.), pp. 103-110. Valgus, Tallinn.

Orviku, K. \& Orviku, K. jun. 1969. Über die Beständigkeit der Entwicklung der Küsten im Estländischen Küstengebiet in der Spätglazialzeit, im Holozän und in der Gegenwart. Eesti NSV TA Toim. Keemia. Geol., 18, 128-139.

Puura, V., Vaher, R. \& Tuuling, I. 1999. Pre-Devonian landscape of the Baltic Oil-Shale Basin, NW of the Russian Platform. In Uplift. Erosion and Stability: Perspectives on Long-term Landscape Development (Smith, B. J., Whalley, W. B. \& Warke, P. A., eds.). Geol. Soc. London. Spec. Publ., 162, 75-83.

Raukas, A. 2004. Klint. In Encyclopedia of Coastal Science (Schwartz, M., ed.), pp. 723-725. Kluwer Academic Publishers B.V., Dordrecht.

Raukas, A. \& Teedumäe, A. (eds.). 1997. Geology and Mineral Resources of Estonia. Estonian Academy Publishers, Tallinn.

Suuroja, K. 2003. Balti klint loodusmälestisena. In Eluta loodusmälestiste uurimine ja kaitse (Pirrus, E., ed.), pp. 19-38. Teaduste Akadeemia Kirjastus, Tartu-Tallinn.

Suuroja, K. 2005. Põhja-Eesti klint. Eesti Geoloogiakeskus, Tallinn.

Tammekann, A. 1926. Die Oberflächengestaltung des Nordestländischen Küstentafellandes. Acta Comment. Univ. Tartuensis, A9, 7, 1-152.

Tammekann, A. 1940. The Baltic Glint. A geomorphological study. Part I. Morphology of the Glint. Publ. Inst. Univ. Tartuensis Geographici, 24, 1-103.

Teichert, C. 1927. Die Klufttektonik der cambro-silurischen Schichtentafel Estlands. Geol. Rundschau, 18, 241-263.

Thamm, N. 1962. The horizontal displacement of the Island Osmussaar (Odinsholm) and the subsequent regeneration of normal rhegmatic jointing. Trans. Geol. Soc. South Africa, $\mathbf{6 5}$, 41-46.

Tuuling, I. \& Flodén, T. 2001. The structure and relief of the bedrock sequence in the GotlandHiiumaa area. Geol. Fören. Stockholm Förhandl., 193, 35-49.

Vilbaste, G. 1939. Põhja-Eesti rannamoodustusi. Tallinn.

\title{
Nõlvaprotsessid Põhja-Eesti paekaldal
}

\author{
Avo Miidel ja Anto Raukas
}

On antud lühiülevaade Põhja-Eesti klindil toimuvatest nõlvaprotsessidest. Viimaseid soodustavateks teguriteks on järsaku ebaühtlane geoloogiline ehitus, tektooniline lõhelisus ja kivimite erinev kõvadus. Protsesside liikumapanevaks jõuks on raskusjõud, mis astub tegevusse, kui kivimites ja pinnases olev vesi on korduvate sulamis-külmumisprotsesside tõttu lõhedega eraldatud kivimiplokid liikumiseks "ette valmistanud". Eristatakse varinguid, aluspõhjalihkeid, ringsilindrilisi lihkeid ja maarooma. Varingud on neist kõige sagedamad, paekalda lääneosas soodustavad nende teket lainetus ja maavärinad. Ringsilindrilised ja aluspõhjalihked on omased Kalvist itta jäävale klindilõigule. Samas on levinud ka maaroomad, millest on haaratud paekaldaesine rusukalle. Selle toimel transporditakse klindist eraldunud aluspõhjapangased rannale. 